\title{
Floristic composition of the cocoa farms infected with the cocoa swollen shoot disease virus (CSSDV) in Marahoué region in the central west of Côte d'Ivoire
}

Aka Romain Aka1*, Bi Tra Aimé Vroh², Walet Pierre N'guessan'1, Klotioloma Coulibaly1, Evelyne Assi ${ }^{1}$, Gnion Mathias Tahi ${ }^{1}$, Brigitte Honorine Guiraud', Kouamé François N'guessan'1, Boubacar Ismaël Kebe ${ }^{1}$, Boaké Kone ${ }^{1}$, Daouda Koné 3

${ }^{1}$ Cocoa program, National Center for Agronomic Research (CNRA), BP 808 Divo, Côte d'Ivoire;

2 UFR Biosciences, University Félix Houphouët-Boigny

3 Université Félix Houphouët-Boigny, WASCAL / CEA-CCBAD, Pôle Scientifique et d'Innovation Bingerville

* Author for correspondence: Email: akaromain@yahoo.fr

Original submitted in on $3^{\text {rd }}$ December 2019. Published online at www.m.elewa.org/journals/ on $29^{\text {th }}$ February 2020 https://doi.org/10.35759/JABs.v146.8

\begin{abstract}
Objective: The overall objective of this study is to develop methods of combatting the cocoa swollen shoot disease. Specifically, it aims to know the floristic composition of the infected cocoa farms in order to identify the host range of the cocoa swollen shoot disease virus (CSSDV) in these farms.

Methodology and Results: The study consisted in floristic surveys conducted in Bouaflé and Sinfra districts, in the Marahoue region in the central west part of Côte d'Ivoire. In each district, infected localities were selected and two infected farms in each locality were chosen for the study. So, 48 infected farms were surveyed using the itinerant inventory method.

Conclusions and application of findings: The surveys identified 253 plant species in the infected farms. These species were grouped into 191 genera and 67 botanical families. Among the 253 species, eight are known as CSSDV reservoirs according to the studies held in Ghana, Togo and Nigeria. These species are Bombax buonopozense P. Beauv. (Bombacaceae), Ceiba pentandra (L.) Gaertn. (Bombacaceae), Cola gigantea var glabrescens Brenan et Keay (Sterculiaceae), Commelina erecta L. (Commelinaceae), Corchorus olitorius L. (Tiliaceae), Pterygota macrocarpa K Schum. (Sterculiaceae), Spondias mombin L. (Anacardiaceae), Sterculia tragacantha Lindl. (Sterculiaceae) L. These species are probably the source of infection in cocoa plantations and must therefore be well known to farmers and other stakeholders. Based on our result an illustrated catalogue can be design for the virus reservoirs recognition. This catalogue can be used to strengthen farmers' knowledge of virus management. Several other weeds are ideal refuges for mealybugs. They must be identified and avoided when creating new farms.
\end{abstract}

Key words: Cocoa Swollen shoot Disease virus, host, Marahoué, Côte d'Ivoire

\section{INTRODUCTION}

The cocoa swollen shoot disease is a serious threat to the sustainability of the cocoa in West Africa. It was reported in Côte d'Ivoire in 1946
(Alibert, 1946). This disease induces a drastic decline in production up to the death of the tree in four to five years after infection (Kouakou, 2014). A 
Badnavirus, member of Caulimoviridae family (Lockhart, 1990), causes the cocoa swollen shoot disease. It is transmitted by around 14 species of mealybugs belonging to the Pseudococcidae family (N'guessan et al. 2019). The most prevalent species are Formicococcus njalensis (Laing), P. citri (Risso), Ferrisia virgata (Okll), Planococcus kenya Le Pelley (Dufour et al 1993, N'guessan et al. 2019). Besides cocoa, the CSSDV can be hosted by several other plant species currently known as the virus reservoir. About 40 species belonging mainly to Sterculiaceae, Bombacaceae and Malvaceae family are listed (Tinsley, 1971 et Partiot, 1983). In the beginning, the CSSDV host plant identification was based on biological indexing, using mealybugs as vectors and Amelonado plant as indicator plant. Two approaches were tested. In the first approach, mealybugs were fed on infected cocoa trees and back inoculated to healthy plant species over than cocoa, then back inoculated to the Amelonado variety. In the second way, mealybugs were directly fed on suspected species found in the infected outbreaks and inoculated on Amelonado plants (Posnette, 1947). Based on the symptoms observed on the Amelonado, the species was declared virus reservoirs (Thresh and Tinsley, 1959). The mechanical inoculation using purified

\section{MATERIALLS AND METHODS}

Surveys locations: The study was conducted in the Marahoué region in central-west of Côte d'Ivoire, specifically in the district of Bouaflé and Sinfra. Marahoué region is between $6^{\circ} 28 ' 29.74$ "and $7^{\circ}$ $44^{\prime} 10.43^{\prime \prime}$ north latitude and $6^{\circ} 7^{\prime} 46.07$ "W and $6^{\circ}$ $47^{\prime} 41.48$ " W of longitude West. It covers an area of $8.500 \mathrm{~km}^{2}$ (Figure 1). The study was implemented in seven locations Bouaflé, Bonon, N'Douffoukankro, Sinfra, Kouétinfla, Bazré and Kononfla. The relief of the region consists of plateaus and plains. The soils resulting from the alteration of these rocks are for the extracts was also tested. In fact, some species was collected on infected farms crushed and the extract was inoculated to cocoa bean freed from their husks or roots of germinated beans through abrasion. However, this technic shows also some issues due to the presence of mucilage, tannins and polyphenols (Brunt and Kenten, 1962). All these constraints in the CSSDV host identification contributed a break in the study. Regarding the importance of the reservoirs in the pathosystem of the swollen shoot disease, it appeared essential to deepen the study with more reliable techniques of screening such as; PCR (Polymerase Chain Reaction) tests combine with a better known of the floristic diversity of the infected cocoa farms. This study is undertaken in Sinfra and Bouaflé districts in Marahoué region (west central) were the disease is known to be endemic (Kébé and N'Guessan, 2003, Kébé et al., 2006, Kouakou, 2006). It is a part of the project of combatting the cocoa swollen shoot disease in Côte d'Ivoire. The overall objective is to identify the host plants of the cocoa swollen shoot virus in the Ivorian cocoa farms. It aims specifically, to know the floristic composition of the infected cocoa farm and determine the most prevalent species in the cocoa swollen shoot outbreaks.

most part ferralitic, moderately desaturated with claysandy dominance. They are characterized by a humid horizon that is not very thick but rich in organic matter, weakly acid and well structured (N'Dri, 1971). The region is influenced by the tropical climate of the Baoulean type with an average annual rainfall between 1998 and 2013 estimated at $1142.52 \mathrm{~mm}$ and an average annual temperature is $31.25^{\circ} \mathrm{C}$. As for relative humidity, it is on average $75 \%$ (ANADER, 2014). 


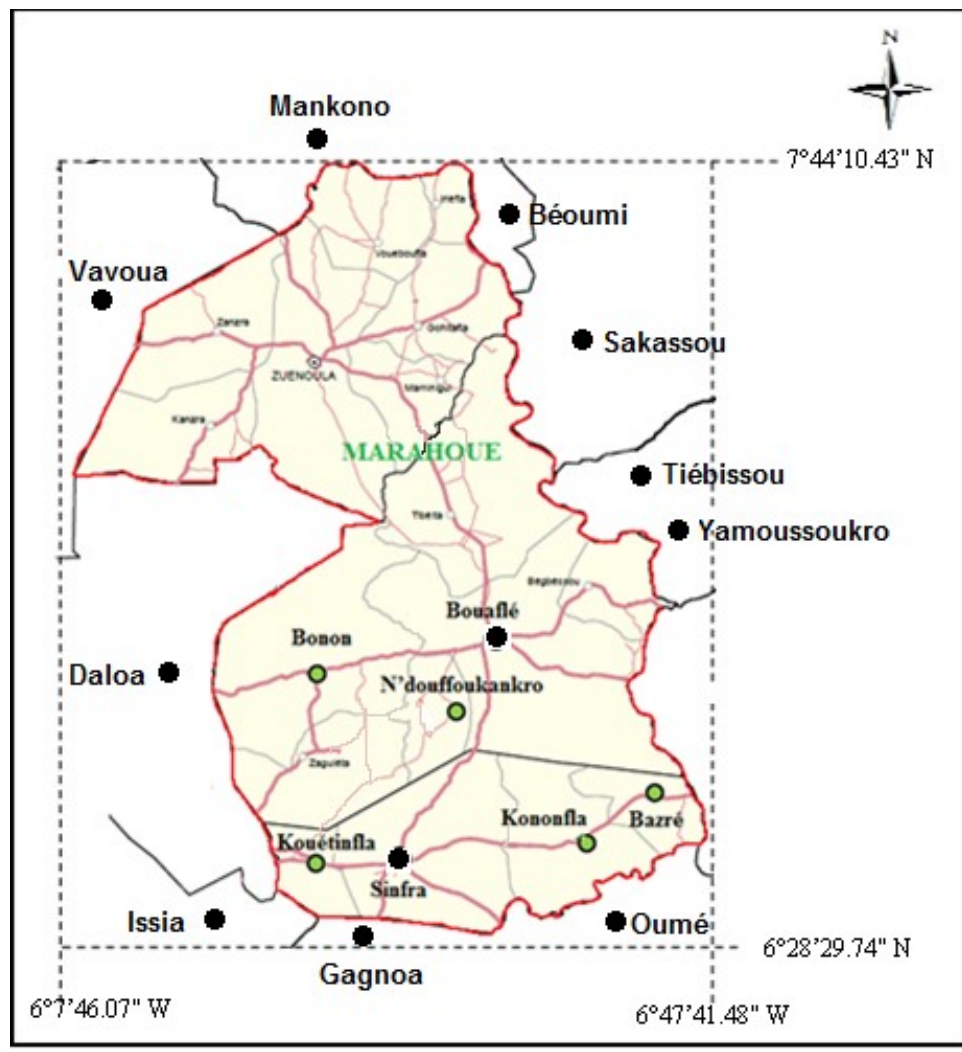

$\begin{array}{lll}0 & 20 \quad 40\end{array}$

80 Kilometers

\section{Caption}

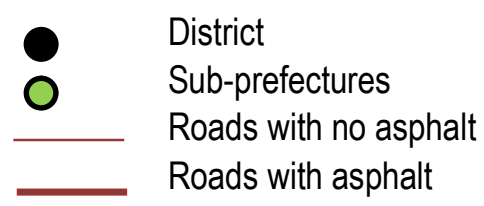

Figure 1: Geographical location of the study area

Floristic survey: For the floristic survey, six subprefectures and four locations in each sub-prefecture were selected. Then two infected farms were targeted in each location. These farms size range is between 1 and 8 ha. They were characterized by the presence of at least one outbreak of infection with a minimum area of $500 \mathrm{~m}^{2}$. The floristic survey was based on the itinerant inventory method (Aké-Assi, 2001, 2002). This method is useful to identify all the plant species encountered on the site. With this method, the outbreak of the CSSDV as well as the remaining of the cocoa farm were fully browsed in order to identify shade trees, weeds and crops associated with cocoa. In this work, undesirable herbaceous plants were considered as weeds, shade trees are plants over eight meters tall and associated crops are those grown up by farmers on the same plot as cocoa (Andrews and Kassam, 1976). For the identification and classification of species and the CSSDV reservoirs, several books of tropical taxonomy, catalogues and herbaria were consulted.

Data analysis: The floristic richness of the infected farms in the Marahoue region was evaluated. It is the number of species recorded on a survey site regardless of their abundance (Aké-Assi, 1984). The absolute and relative frequencies of the species were calculated. According to Godron (1968), the absolute frequency (Fa) of each species is the total of its occurrences in all the surveys carried out and the relative frequency (Fr) of a given plant species is the ratio of its occurrence out of the total of surveys carried out (N). It is expressed as:

\section{$\mathrm{Fr}=(\mathrm{Fa} / \mathrm{N}) \times 100$}

The species recorded in the Ivorian cocoa have been described based on two parameters: chorological affinities and biological types. Chorological affinities explain the geographical distribution of species. It was based on a set of abbreviations: Guineo-Congolese taxon (GC), Common taxon to the Guineo-Congolese region and the Sudano-Zambezi region (GC-SZ), Endemic taxon of the forest block in western Togo, including Ghana, Côte d'Ivoire, Liberia, Sierra Leone, Guinea, Guinea Bissau, Gambia and Senegal (GCW), introduced or cultivated Taxon (I), and Taxon of the Sudano-Zambezian region (SZ). The biological types are a plant classification system initiated by Raunkiaer (1934), in order to organize all the plants according to the positioning of the survival organs of the plant during the unfavorable period. In order to facilitate this 
description, a set of abbreviations related to this parameter was used: Chaméphyte (Ch), epiphyte (Ep), Geophyte (G), hemicryptophyte (H),

\section{RESULTS}

Floristic diversity of the infected cocoa farms: The floristic surveys carried out in the infected cocoa farms of Bouaflé and Sinfra brought out 253 species grouped in 191 genera and 67 botanical families. The extrema values are 136 and 60 species with an average of 89 species (Table 1). The 253 species are distributed in Dicotyledons, Monocotyledons and Pteridophytes. Dicotyledons represent $84.38 \%$ of the species with 53 families, 161 genera and 216 species. Monocotyledons represent $14.84 \%$ of the species. There are grouped into 12 families, 28 genera and 38 species. Pteridophytes constitute $0.78 \%$ of this flora with two genera and two families. The most represented families are Euphorbiaceae, Poaceae, Fabaceae, Asteraceae, Moraceae, Rubiaceae, Solanaceae, Sterculiaceae, Malvaceae and Acanthaceae with total of 122 species (Table 2). The species found in the farms have been divided into three categories the weeds $(\mathrm{Wd})$, the intercrops (Ic) and the shade trees (St). The weeds are 177 species, grouped into 50 families. The most abundant species are Chromolaena odorata (L.) King \& H. Rob. (Asteraceae), Euphorbia heterophylla L. (Euphorbiaceae), Panicum laxum Sw. (Poaceae), Pothomorph umbellata (L.) Miq. (Piperaceae), Solanum erianthum D. Don, Alchornea cordifolia (Schum. \& Thonn.) Mull. Arg. (Euphorbiaceae). The intercrops are 17 species belonging to 11 botanical families. The most prevalent are Carica papaya L. (Caricaceae), Capsicum frutescens L. (Solanaceae), Manihot esculenta Crantz (Euphorbiaceae); Dioscorea cayenensis Lam., Xanthosoma mafaffa Schott (Araceae), Persea americana Mill., Dioscorea alata L. (Dioscoreaceae), Solanum distichum Schum. \& Thonn. and Solanum macrocarpon L. (Solanaceae). The shade trees are $22.75 \%$ of the floristic composition of the infected cocoa farms. There are 58 species belonging to 20 botanical families. The most popular species are Ceiba pentandra (L.) Gaertn., Ficus exasperata Vahl, Anacardium occidentalis L., Annona muricata L., Antiaris toxicaria var., Celtis mildbraedii Engl, Cola gigantea var glabrescens Brenan and Keay, Pouteria alnifolia (Baker) Roberty. and Spondias mombin L. (Table 3). The comparative analysis of the species recorded in the Ivorian cocoa farms and those found in Africa, shows that the majority of the cocoa flora in the megaphanerophyte (MP), mesophanérophyte (mP), microphanerophytes (mp), nanophanerophyte (np), parasite (Par), Therophyte (Th) and stolon (Sto).

Marahoue region is representative of the taxa of the Guineo-Congolese region at $48.05 \%$, GuineoCongolese and Sudan-Zambezian regions at $40.23 \%$. Introduced or cultivated taxa (i) at $8.98 \%$. The endemic taxa of the forest block in western Togo, including Ghana, Côte d'Ivoire, Liberia, Sierra Leone, Guinea, Guinea Bissau, Gambia and Senegal (GCW) and the Sudan-Zambezian (SZ) region are poorly represented. They account for 1.95 and $0.78 \%$ respectively (Figure 2 ). The flora of the cocoa tree in the Marahoue region is characterized by 14 biological types (Figure 3 ). The most abundant species belong to the microphanerophytes, including the lianacent types and the nanophanerophytes. Together, they are 141 species, representing more than $55 \%$ of the flora. They are followed by therophytes (11.72\%) and mesophanerophytes (10.55\%). The chaméphytes, hemicryptophytes, megaphanérophytes, nanophanerophytes lianescent and rhizomatous geophytes are respectively $5.47 \%, 4.69 \%, 4.30 \%$ and $3.125 \%$ for the last two. Epiphytic, parasitic, hemicryptophyte and stolon species are the minor one together they contribute to $1.95 \%$.Situation of the CSSDV potential host range in the outbreaks of infection: This study allows to identify a shortlist of eight species ever know as cocoa swollen shoot virus reservoirs accordingly to the studies held in Ghana, Togo and Nigeria. These species are Bombax buonopozense (P. Beauv.) (Bombacaceae), Ceiba pentandra (L.) Gaertn. (Bombacaceae), Cola gigantea var glabrescens Brenan et Keay (Sterculiaceae), Commelina erecta L. (Commelinaceae), Corchorus olitorius L. (Tiliaceae), Pterygota macrocarpa K Schum. (Sterculiaceae), Spondias mombin L. (Anacardiaceae), Sterculia tragacantha Lindl. (Sterculiaceae) L. They were recorded in at least $50 \%$ of the outbreaks of the disease. Beside these species, some are frequently (with more than $75 \%$ of relative frequencies) recorded in the swollen shoot outbreaks. These are Chromolaena odorata (L.) King \& H. Rob. Asteraceae, Euphorbia heterophylla L. (Euphorbiaceae), Solanum eriantum D. Don (Solanaceae), Carica papaya L. (Caricaceae), Coccinia grandis (L.) Voigt (Cucurbitaceae), Ficus exasperata Vahl (Moraceae), Laportea aestuans (L.) Chew (Urticaceae). 
Aka et al., J. Appl. Biosci. 2020 Floristic composition of the cocoa farms infected with the cocoa swollen shoot disease virus (CSSDV) in Marahoué region in the central west of Côte d'Ivoire

Table 1: Distribution of species identified by localities

\begin{tabular}{|c|c|c|c|}
\hline Districts & Sub-prefecture & Localities & Effective of species recorded \\
\hline \multirow{12}{*}{ Bouaflé } & \multirow{4}{*}{ Bouaflé } & Garango & 92 \\
\hline & & Sokrolaye & 136 \\
\hline & & Bozi & 104 \\
\hline & & N'dehnoukro & 95 \\
\hline & \multirow{4}{*}{ Bonon } & Petit Gohitafla & 70 \\
\hline & & Bognonzra & 83 \\
\hline & & Blablata & 106 \\
\hline & & Dabouzra & 115 \\
\hline & \multirow{4}{*}{ N'douffoukankro } & Blé & 86 \\
\hline & & Blanfla & 92 \\
\hline & & Atossé & 74 \\
\hline & & N'Douffoukankro & 98 \\
\hline \multirow{12}{*}{ Sinfra } & \multirow{4}{*}{ Bazré } & Odiénékaman & 40 \\
\hline & & N'zikro & 60 \\
\hline & & Sokobakro & 80 \\
\hline & & Kouamékro & 74 \\
\hline & \multirow{4}{*}{ Kouétinfla } & Gbrizokro & 83 \\
\hline & & Kouétinfla & 123 \\
\hline & & Yanantinfla & 110 \\
\hline & & Kouroudoufla & 96 \\
\hline & \multirow{4}{*}{ Kononfla } & Kayéta & 85 \\
\hline & & Karamasso & 63 \\
\hline & & Koumoudji & 74 \\
\hline & & Djamalakro & 96 \\
\hline
\end{tabular}

Table 2: Indices of diversity of the ten most represented botanical families of the flora of the infected cocoa trees of the Marahoué region

\begin{tabular}{|c|l|c|c|c|}
\hline $\mathbf{N}^{\circ}$ & Sotanical Families & Genus & Ids \\
\hline 1. & Acanthaceae & 7 & 5 & 1,4 \\
\hline 2. & Asteraceae & 14 & 13 & 1,08 \\
\hline 3. & Euphorbiaceae & 21 & 15 & 1,4 \\
\hline 4. & Fabaceae & 17 & 12 & 1,42 \\
\hline 5. & Malvaceae & 8 & 4 & 2 \\
\hline 6. & Moraceae & 10 & 4 & 2,5 \\
\hline 7. & Poaceae & 18 & 14 & 1,29 \\
\hline 8. & Rubiaceae & 9 & 9 & 1 \\
\hline 9. & Solanaceae & 9 & 3 & 3 \\
\hline 10. & Sterculiaceae & 9 & 8 & 1,125 \\
\hline TOTAL & & $\mathbf{1 2 2}$ & $\mathbf{8 7}$ & - \\
\hline
\end{tabular}




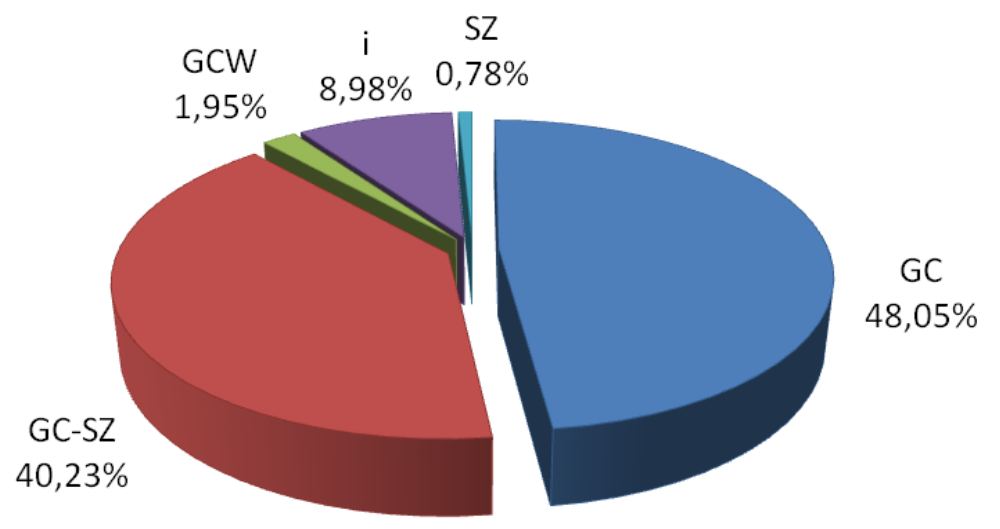

Figure 2: Distribution of species by chorological affinity in Africa

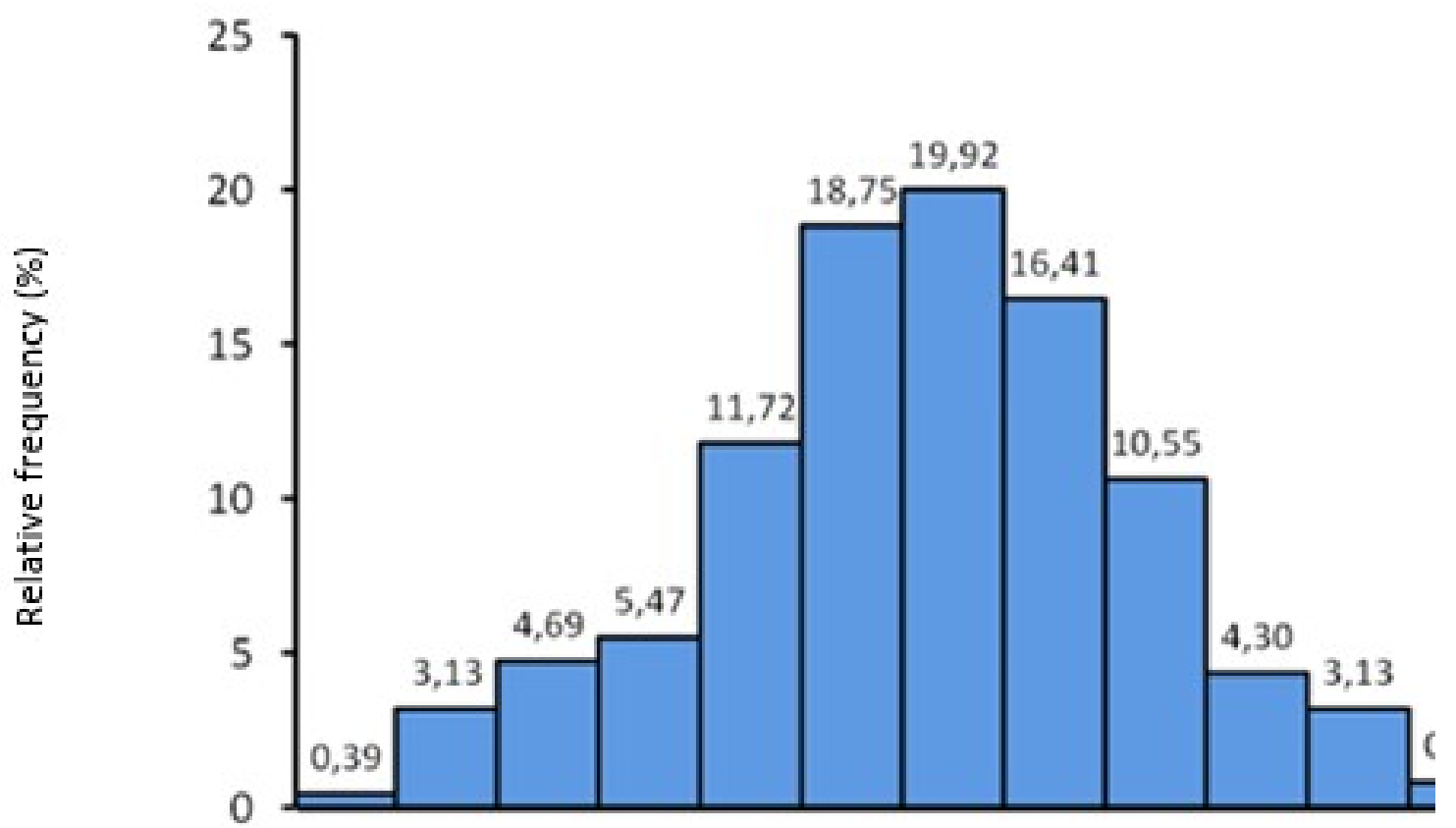

Figure 3: Different biological types identified in the infected cocoa farms of Marahoué

Table 3: List of the most common plant species in outbreaks of infection

\begin{tabular}{|r|l|l|l|}
\hline $\mathbf{N}$ & Species & Botanical Familly & Relative Fréquency (\%) \\
\hline 1. & Chromolaena odorata (L.) King \& H. Rob. & Asteraceae & 100,00 \\
\hline 2. & Euphorbia heterophylla L. & Euphorbiaceae & 100,00 \\
\hline 3. & Solanum eriantum D. Don & Solanaceae & 100,00 \\
\hline 4. & Carica papaya L. & Caricaceae & 83,33 \\
\hline 5. & Ceiba pentandra (L.) Gaertn. & Bombacaceae & 83,33 \\
\hline 6. & Coccinia grandis (L.) Voigt & Cucurbitaceae & 83,33 \\
\hline 7. & Ficus exasperata Vahl & Moraceae & 83,33 \\
\hline 8. & Laportea aestuans (L.) Chew & Urticaceae & 83,33 \\
\hline 9. & Adenia cissampeloides (Planch. ex Hook.) Harms & Passifloraceae & 66,67 \\
\hline 10. & Ageratum conyzoides L. & Asteraceae & 66,67 \\
\hline 11. & Antiaris toxicaria var africana (Engl) C. C; Berg & Moraceae & 66,67 \\
\hline
\end{tabular}


Aka et al., J. Appl. Biosci. 2020 Floristic composition of the cocoa farms infected with the cocoa swollen shoot disease virus (CSSDV) in Marahoue region in the central west of Côte d'Ivoire

\begin{tabular}{|l|l|l|l|}
\hline 12. & Capsicum frutescens L. & Solanaceae & 66,67 \\
\hline 13. & Griffonia simplicifolia (Vahl ex DC.) Baill. & Caesalpiniaceae & 66,67 \\
\hline 14. & Manihot esculenta Crantz & Euphorbiaceae & 66,67 \\
\hline 15. & Milletia zechiana (Welw.) C. C Berg & Fabaceae & 66,67 \\
\hline 16. & Mondia whytei (Hook. f.) Skeels & Periplocaceae & 66,67 \\
\hline 17. & Parquetina nigrescens (Afz.) Bullock & Periplocaceae & 66,67 \\
\hline 18. & Paspalum conjugatum Berg. & Poaceae & 66,67 \\
\hline 19. & Pouzolzia guineensis Benth & Urticaceae & 66,67 \\
\hline 20. & Spathodea campanulata P. Beauv. & Bignoniaceae & 66,67 \\
\hline 21. & Spondias mombin L. & Anacardiaceae & 66,67 \\
\hline 22. & Syndrella nodiflora Gaertn. & Asteraceae & 66,67 \\
\hline 23. & Xanthosoma mafaffa Schott & Araceae & 66,67 \\
\hline 24. & Albizia adianthifolia (Schum.) W. F. Wight & Mimosaceae & 50,00 \\
\hline 25. & Bombax buonopozense P. Beauv. & Bombacaceae & 50,00 \\
\hline 26. & Centrosema pubescens Benth & Fabaceae & 50,00 \\
\hline 27. & Clerodendrum umbellatum Poir & Verbenaceae & 50,00 \\
\hline 28. & Commelina erecta L. & Commelinaceae & 50,00 \\
\hline 29. & Cyathula prostrata (L.) Blum. & Amaranthaceae & 50,00 \\
\hline 30. & Dioscorea cayennensis Lam. & Dioscoreacea & 50,00 \\
\hline 31. & Ficus sur Forssk & Moraceae & 50,00 \\
\hline 32. & Ipomoea triloba L. & Convolvulaceae & 50,00 \\
\hline 33. & Momordica charantia L. & Cucurbitaceae & 50,00 \\
\hline 34. & Morinda lucida Benth. & Rubiaceae & 50,00 \\
\hline 35. & Morus mezozygia Stapf & Moraceae & 50,00 \\
\hline 36. & Panicum brevifolium (Link) Kunth & Poaceae & 50,00 \\
\hline 37. & Persea americana Mill. & Lauraceae & 50,00 \\
\hline 38. & Rottboellia cochinchinensis (Lour.) Clayton & Poaceae & 50,00 \\
\hline 39. & Solanum torvum Sw. & Solanaceae & 50,00 \\
\hline 40. & Spigelia anthelmia L. & Loganiaceae & 50,00 \\
\hline & & & \\
\hline
\end{tabular}

\section{DISCUSSION}

This study allows understanding of the great diversity of the flora of the infected cocoa farms of the Marahoué region. This flora is rich of 253 species, so, 129 more than a normal adult cocoa farm of the region (Konan, 2009). In fact, Konan in 2009 shows that in the region, an adult cocoa farm is rich of about 124 species. In our study, the weeds appear to be the most abundant. They have been identified in the CSSDV outbreaks where the canopy is destroyed. In addition, noticed more intercrops were noticed. These crops are also grown up in the outbreaks according to the food habits of the farmer (Boni, 1985). Some species such as banana trees (Musa paradisiaca L. and Musa sapientum L.) are originally used to provide temporary shade to young cocoa trees, while others such as cola tree and palm trees are mainly spontaneous crops. Some trees are also preserved in the cocoa tree because of their medicinal or cultural values (Assiri, 2010). The majority of the flora of the infected cocoa trees in the Marahoué region is representative of the taxa of the GuineoCongolese and Sudano-Zambezian regions. This distribution attests that the cocoa lands of the Marahoue are located in the savannah-forest contact zone. Indeed, the conception of the phytogeography of Sub-Saharan Africa according to White (1986) shows that Côte d'Ivoire is in the Guineo-Congolese, Zambezian and Sudanian phytogeographical regions. The Guineo-Congolese region is characterized physionomically by a widely extended forest landscape of dense evergreen, semi-evergreen, swampy, flooded and secondary rainforests derived from climax degradation. The Zambezian and Sudanian regions have a landscape dominated by xeric grasslands and light Zambezian and Sudanian clear forests (Kapa, 1998). The study shows also that some species identify as CSSDV reservoirs in other countries are recorded in Marahoué's cocoa orchard. Among them Bombax buonopozense (P. Beauv.), Ceiba 
pentandra (L.) Gaertn. Commelina erecta L. and Spondias mombin L. species are highly present in the Outbreaks of the disease. Bombax buonopozense, Ceiba pentandra (L.) Gaertn and Spondias mombin was first described as CSSDV reservoirs in Ghana in 1950 by Posnette (Posnette et al., 1950). The Pterygota macrocarpa K Schum. Cola gigantea var glabrescens Brenan et Keay, Corchorus olitorius L., Sterculia tragacantha Lindl.

\section{CONCLUSION AND PERSPECTIVES}

This study is a starting point on the identification of the CSSDV host plants in Côte d'Ivoire. In fact, the floristic composition of the cocoa farms infected with the cocoa swollen shoot virus (CSSDV) in the Marahoue region in Côte d'Ivoire highlighted the specific richness of infected cocoa farms, with more than 253 species listed. From these species, eight are known to host the CSSDV, according to the studies undertaken in Ghana, Togo and Nigeria. The most prevalent among these species have a less proportion. Some species as Chromolaena odorata (L.) King \& H. Rob. (Asteraceae), Euphorbia heterophylla L. (Euphorbiaceae), Solanum eriantum D. Don (Solanaceae), Carica papaya L. (Caricaceae), Coccinia grandis (L.) Voigt (Cucurbitaceae), Ficus exasperata Vahl (Moraceae), Laportea aestuans (L.) Chew (Urticaceae) are not known as the virus reservoir but was commonly found in the CSSDV outbreaks.

species are: Ceiba pentandra (L.) Gaertn. (Bombacaceae), Spondia mombin L. (Anacardiaceae), Bombax buonopozense P. Beauv (Bombacaceae), Commelina erecta L. (Commelinaceae). As potential virus reservoirs, it is necessary to continue this study through a leave sampling on the infected trees for the virus detection. The virus detection will be based on the use of reliable techniques' such as PCR.

\section{ACKNOWLEDGEMENTS}

The authors are grateful to the Conseil Du Café Cacao of Côte d'Ivoire for funding this research through the FIRCA (Fond Interprofessionnel pour la Recherché et le conseil Agricole).

\section{BIBLIOGRAPHICAL REFERENCES}

ANADER Bouaflé, 2014. Monographic study of the department of Bouaflé, $9 \mathrm{P}$

Aké-Assi L., 1984. Flora of Côte d'Ivoire: Descriptive and biogeographic study, with some ethnobotanical notes. Volume I, II, III. Thesis Doct. Es-Sc. Nat. F.A.S.T., University of Cocody, Abidjan, 1205p.

Aké-Assi L., 2002. Flora of the Ivory Coast 2: systematic, biogeographic and ecological catalogue. Conservatory and Jard. Bot., Geneva, Switzerland, Boissera 58, $401 \mathrm{p}$.

Alibert, $H_{.}, 1946$. Preliminary note on a new cocoa disease "swollen shoot". Tropical Agronomy, Paris, V.1, pp. 34-43.

Andrews D. J. and Kassam A. H., 1976. The importance of multiple cropping in increasing world food supplies. P. 1-10 In R.I. Papendick, A. Sanchez, G.B. Triplett (Eds.), Multiple Cropping. ASA Special Publication 27. American Society of Agronomy, Madison, WI.

Assiri A. A., 2010, Study of cocoa regeneration in Côte d'Ivoire: Impact of rehabilitation and replanting techniques on the development and productivity of cocoa orchards (Theobroma cacao L.) in relation to soil conditions. Thesis dissertation, $170 p$

Boni D., 1985. The plantation economy in the Ivory Coast forest. New Editions Africaines, Abidjan, $458 \mathrm{p}$.

Brunt A. K. et Kenten R. H., 1962. Mechanical Transmission of cocoa swollen shoot virus to and from cocoa and other host Ann. Appl. Biol., 50, p. 749-754

Dufour B., Djiekpor E. K., Paulin D. et Cilas C., 1993. Screening method for resistance to swollen shoot virus: Improvement of transmission by mealybug. In: Proceedings of the 11th International Conference on Cocoa Research. Yamoussoukro, Côte d'Ivoire, pp. 243-244.

Dufour B., 1987. Use of a transmission method for the identification of Togolese forms of the cocoa swollen shoot. First results. In: Proceedings of the 10th International Conference on Cocoa Research. Santo Domingo, Dominican Republic, pp. 521-526.

Dale, W. T. 1962. Diseases and pests of cocoa. A. virus diseases. Pages 286-316 in Agriculture and land use in Ghana, J.B. Wills (Ed.). Oxford University Press, London, UK. 
Godron M. 1968. "Some applications of the notion of frequency in plant ecology", Oecol. Plant. (3): 185-212.

Kapa BF, 1998. Center for Information Exchange of the Democratic Republic of Congo, Convention on Biodiversity, State of Biological Diversity in the Democratic Republic of Congo on the Network since 28 August 1998, http: // bch-cbd .naturalsciences.be / congodr / cdr-ra / contribution /. Last update: 16-02-2004

Kébé I. B., Koffié K., N'Guessan K. F., Assiri A. A., Adiko A., Aké. S., Anno P A., 2006. The swollen shoot in Côte d'Ivoire: current situation and prospects. In 15th International Cocoa Research Conference. Pp 901-922.

Kébé B. I. and N'guessan K. F., 2003. Report of the prospecting mission of the swollen shoot. 11 13 September 2003. C.N.R.A - Divo, 7 pp.

Konan D., 2009. Evaluation of the impact of cocoa farming on flora and vegetation in semideciduous wet dense forest zone: case of the Department of Oume. Memory of DEA. $37 p$

Kouakou K. 2014. Molecular diversity of the CSSS (Cocoa swollen shoot virus) and epidemiology of swollen cocoa shoot disease (Theobroma cacao L.) in Côte d'Ivoire. Doctorate thesis Phytovirology, Publicly supported Thursday, March 13, 2014, $134 p$

Kouakou, K., Kébé, B. I., Kouassi, N., Aké, S., Cilas, C., and Muller, E. 2012. Geographical distribution of Cacao swollen shoot virus molecular variability in Côte d'Ivoire. Plant Dis. 96:14451450.

Kouakou K. 2006. Epidemiology of swollen cocoa shoot disease: Theobroma cacao I. (Sterculiaceae) in the sub-prefecture of Bazre (center of the Ivory Coast). Master's Degree in Advanced Studies in Plant Physiology Option: Agrophysiology, at UFR Biosciences, Isoutenu le 11 janvier 2006, $89 p$

Lockhart B. E. L., 1990. Evidence for a double-stranded circular DNA genuine in a second group of plant viruses. Phytopathology 80, 127-131.

N'Dri D., 1971. Soil study Bozi Marahoué, Soil report, $29 \mathrm{p}$.

N'Guessan W. P., Yapi A., N'Guessan K. F., Kouamé N. N. Gouamené N. C., Aka R. A., Coulibaly K. Tahi G. M., Koné B., Kassin K. E., Assi Marise E., Guiraud B. S. B. H., Kotaix A. J. A., 2019. Inventory and abundance of mealybug species in immature and mature cocoa farms in Côte
d'Ivoire, Journal of Applied Entomology, https://doi.org/10.1111/jen.12707

Owusu C. K., 1972. Acquisition of swollen shoot virus by mealybugs from cocoa plant during the period of talent infection. Ann. Rep. Cocoa res. Inst. Ghana, 169-70, 60

Partiot M., 1983. The Cocoa Swollen Shoot (Theobroma cacao L., Sterculiaceae): A study of the nature and evolution of a host-parasite pair in a tropical ecosystem. Thesis of State doctoral degree.

Posnette, 1947, Seed Transmission, Nature, vol 159, 500-501

Raunkiaer C., 1934. The life form of plants and statistical plant geography. Clarendon press, Oxford. $632 \mathrm{p}$.

Tinsley T. W., 1971. The role of wild hosts in the incidence of swollen shoot virus in West Africa In the ecology of cacao viruses

Thresh J. M., 1981. The role of weeds and wild plants in the epidemiology of plant virus disease. In: pests, pathogens and vegetation, Tresh J.M. ed., pitman; London, GB, 53-70.

Thresh J.M. et Tinsley W., 1959. The viruses of cacao. Tech. Bull. W. Afr. Cocoa Res. Inst. 7, 1-32

Thresh J. M., 1958. The spread of virus disease. In: Technical Bulletin $n^{\circ} 5$. Published on behalf of the West African Cocoa Research Institute. By the Crown Agents for Oversea Governments and Administrations, 4, Millbank, London, S.W.I., 36p.

Tinsley W. et Wharton A. L., 1958. Studies on the host range of viruses from Theobroma Cacao $\mathrm{L}$. Ann. App. Biol. (londre), 46, pp. 1-6

White F., 1986. The vegetation of Africa. Submission to the UNESCO / AETFAT / UNSO.- ORSTOM and UNESCO UNESCO Vegetation Map, Paris, Natural Resources Research Series, No. $20,384 \mathrm{p}$. 